\title{
DOS PABELLONES
}

\section{TWO PAVILIONS}

\section{Guillermo Hevia García}

Profesor Asistente Adjunto, Escuela de Arquitectura, Pontificia Universidad Católica de Chile Santiago, Chile
Nicolás Urzúa

\author{
Profesor Asistente Adjunto, Escuela de Arquitectura, \\ Pontificia Universidad Católica de Chile \\ Santiago, Chile
}

A collection of images is the starting point of two projects that, while similar in their formal resolution and conceptual origin, differ in their location and materials, revealing that form can be conditioned by other variables, producing completely different imaginaries from a shared origin.

KEYWORDS · collection, images, curves, pavilions, open systems

A collection in constant construction and revision is the starting point of these projects, enabling to fill with content two pavilions without any specific program. Made out of personal interests, obsessions, research lines, artworks, cinema fragments, literary pieces, objects, photographs, paintings and memories, this collection is the substrate from which each of the projects develops, and allows establishing relations that respond to a personal cultural construction - a subjective imaginary.

The pavilions involve creating atmospheres shaped by curves and counter-curves of slim, almost two-dimensional elements. Rather than finished products, an open construction and structural strategy has been proposed, which allows building multiple spaces enabling the adaptation to different geometries, environments or places.

In the case of Los Bosques [The Woods], these sites have been considered a recurrent theme in literature, mythology, painting and the arts in general. Thus, in this project, we have sought to transfer sensory stimuli that go beyond the visual and have to do with touch, smell or temperature. The curved-based configuration of the plan derives either from real logs' sections or from those transferred to paper as the artist Bryan Nash Gill does, or as in George Nakashima's furniture. Wooden panel construction is related to screens made by Alvar Aalto or the Eames, abandoning in this pavilion the domestic scale to get closer to that of the building.

In Tu Reflexión [Your Reflection] pavilion, the opaque material has been replaced by reflection, so as to lose control 
LOS BOSQUES
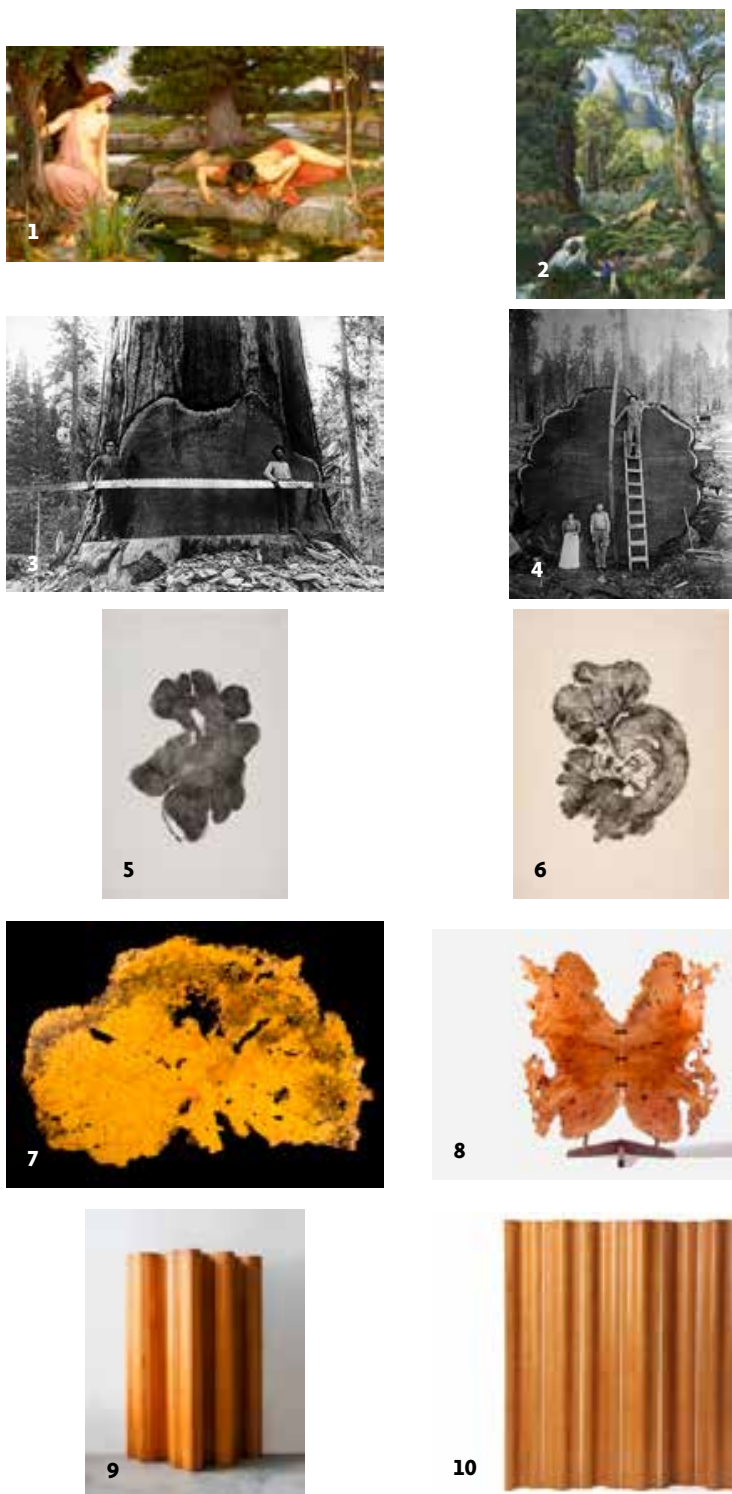
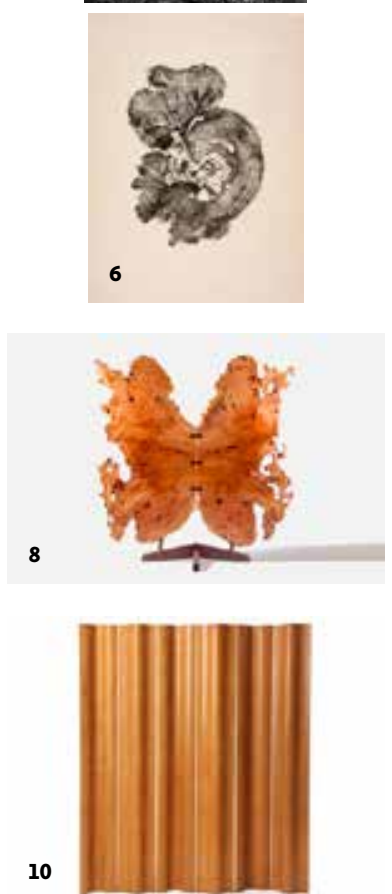

1 John William Waterhouse, Echo and Narcissus, 1903. (C) Creative Commons | 2 Karl Friedrich Philipp von Martius, Morenia Pöppigiana, c. 1850. (C) Creative Commons | 3 y 4 California, USA, 1917 | 5 Bryan Nash Gill, Woodcut Maple, 2012. $36^{13} / 16^{11} \times 24^{13} / 16^{\prime \prime}$. (C) Bryan Nash Gill | 6 Bryan Nash Gill, Woodcut Cedar Burl, 2011, 33 1/16" $\times 24716^{\prime \prime}$. (c) Bryan Nash Gill 7 George Nakashima, Cofee Table 3, 1977. (c) George Nakashima | 8 George Nakashima, Tsuitate Butterfly Gate, 2011. (c) George Nakashima | 9 Alvar Aalto, Pinewood Screen, Model 100, c. 1940. (c) Alvar Aalto Foundation | 10 Charles \& Ray Eames, Plywood screen 01, 1946-1955. ( Eames Foundation
TU REFLEXIÓN

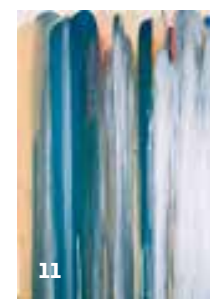

12
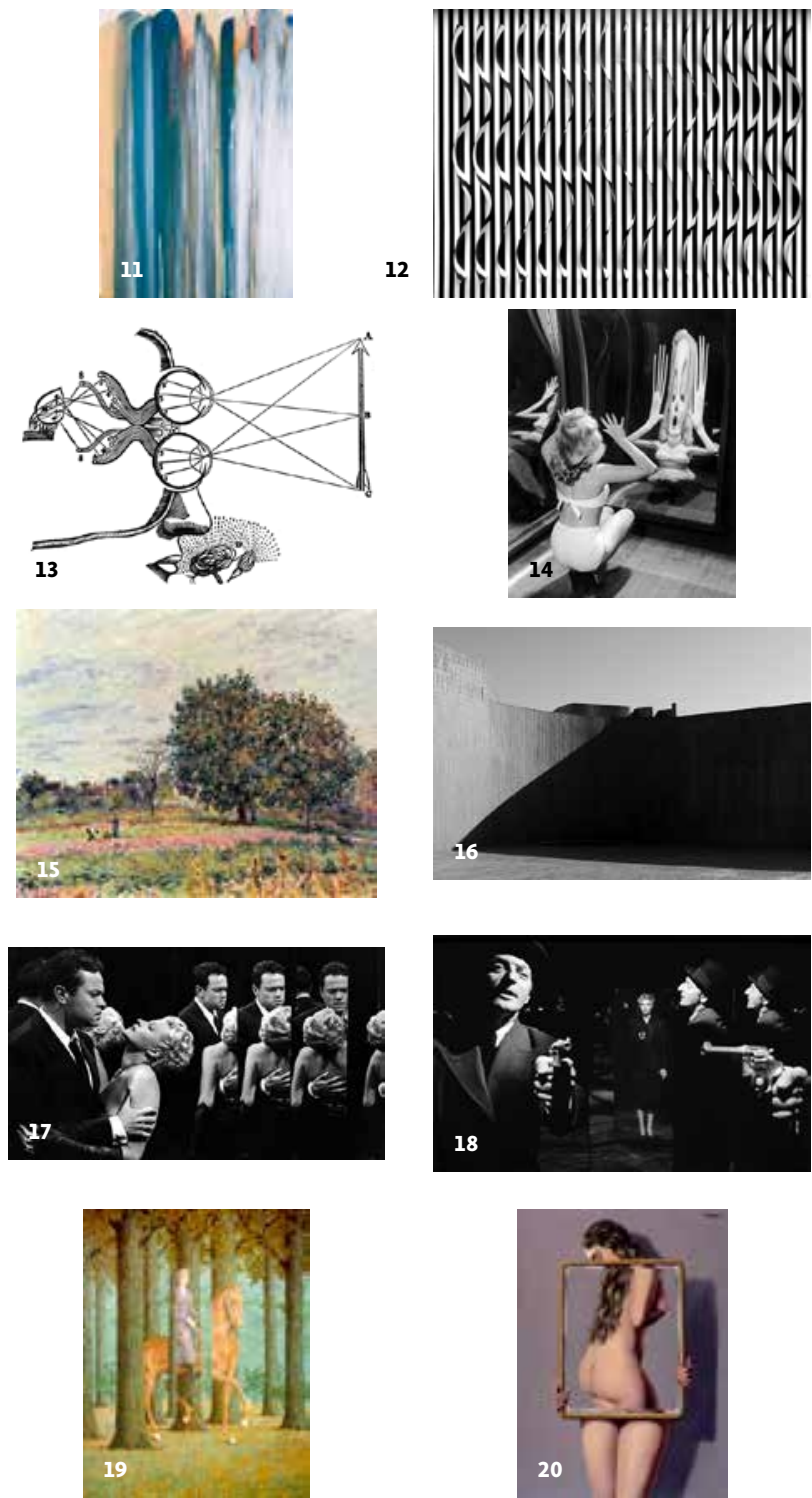

11 John Armleder, Sans titre, 1994. () John Armleder | 12 Julio Le Parc, Desplazamientos, 1976. (C) Julio Le Parc | 13 René Descartes, Vision and visual perception, $16^{\text {th }}$ century. Fuente / Source: www.beaumontvision.com | 14 House of mirrors. (c) Andre Kertesz |

15 Alfred Sisley, Walnut trees at sunset in early october, 1882. (c) Creative Commons | 16 José Antonio Coderch, Ampliación Escuela Superior de Arquitectura de Barcelona, 1978. (c) Familia Coderch $\mathbf{1 7}$ y 18 Orson Welles, The lady from Shanghai, 1947. Fuente / Source: http://cinearchive.org | 19 René Magritte, La Carte Blanche, 1965. C Fondation René Magritte | 20 René Magritte, Les Liaisons dangereuses, 1936. (C) Fondation René Magritte

over the project. We wanted to transfer the focus of the proposal from the built object to the subject that experiences it. In this sense, the project is closer to the construction of an experience whose possibility of reflection, deformation and multiplication of people and the context is almost infinite, causing an interaction closer to illusion than to reality. ARQ 
LOS BOSQUES

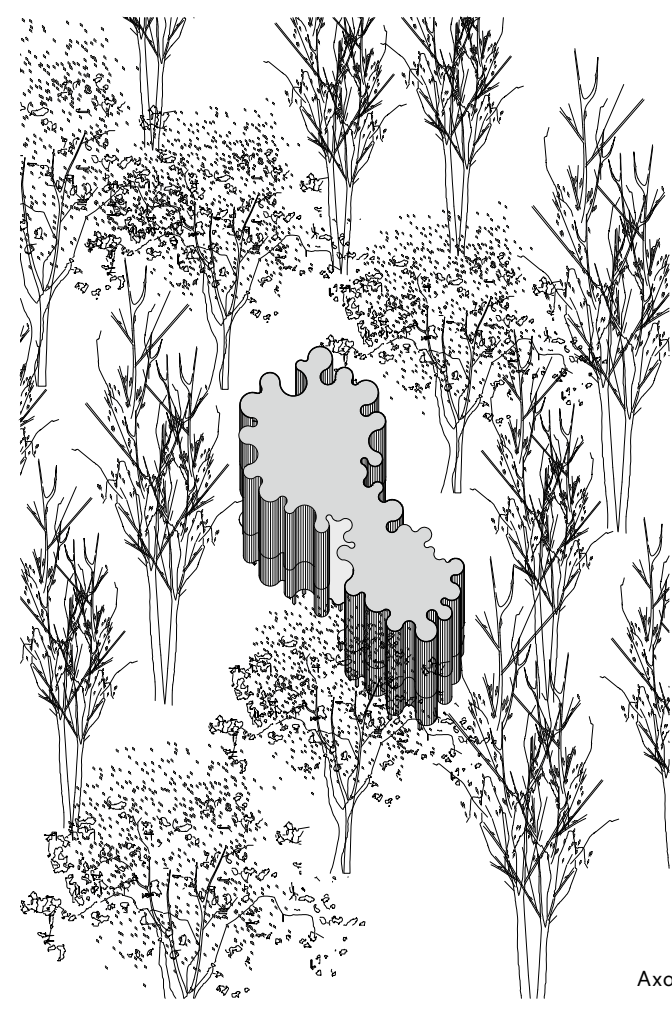

Axonométrica / Axonometric

S. E. / N. S.
TU REFLEXIÓN
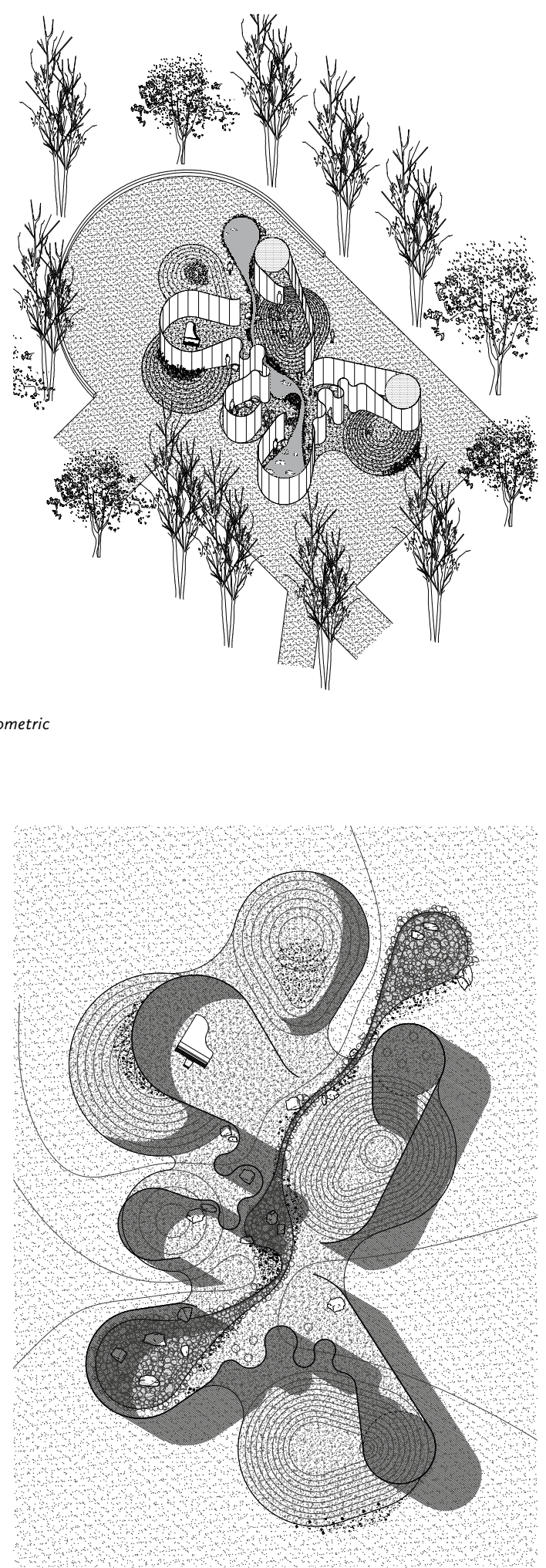
LOS BOSQUES

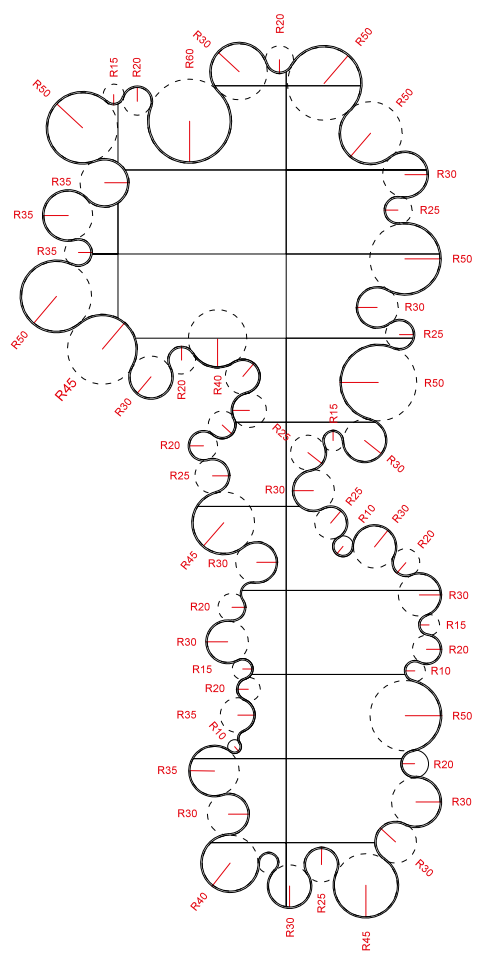

TU REFLEXIÓN
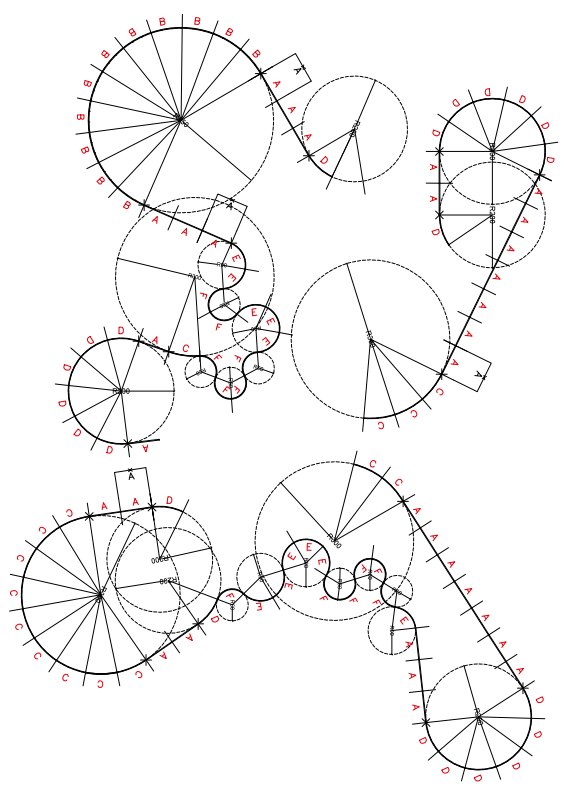

Planta configuración geométrica / Geometric plan configuration

S. E. / N. S.
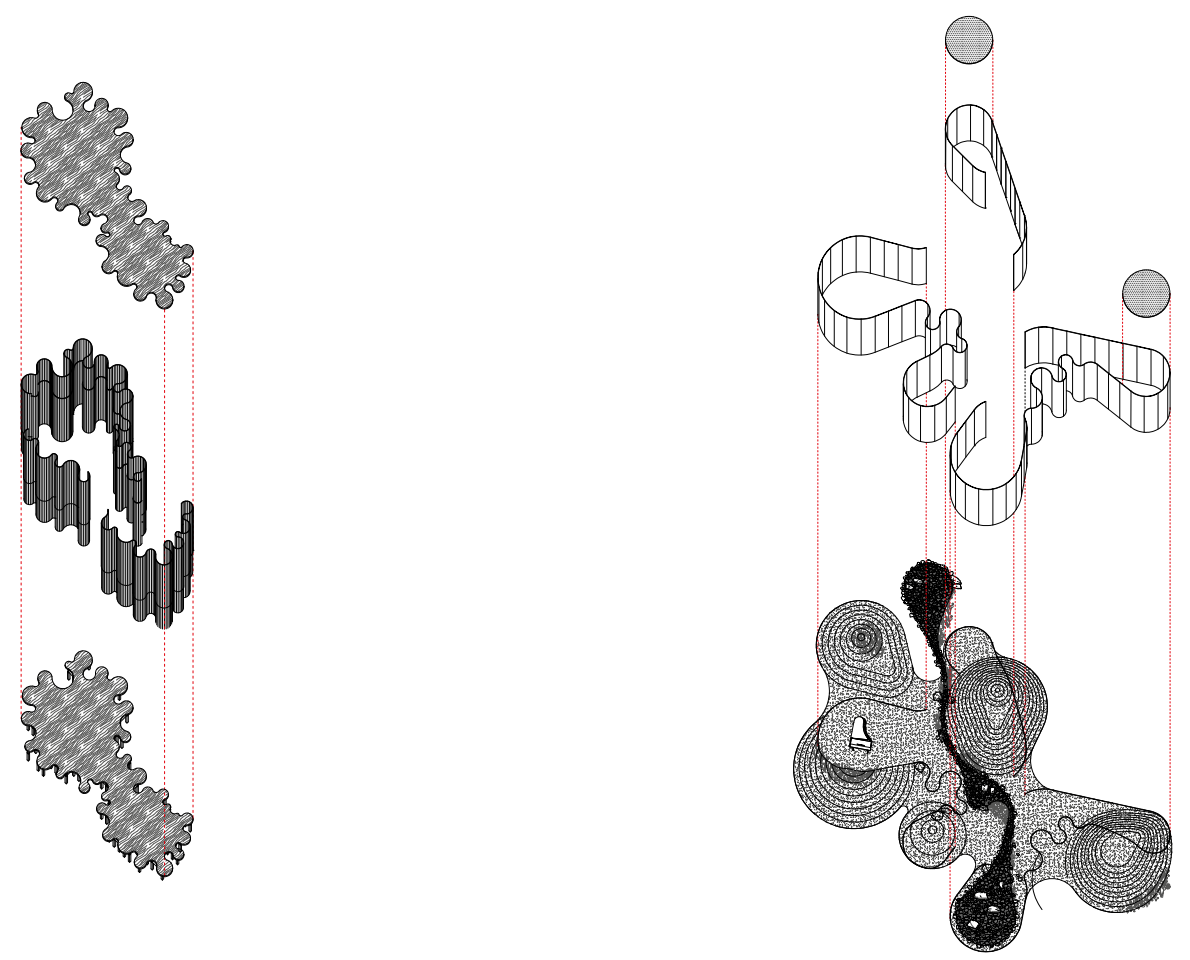

Axonométrica proyectada / Axonometric projection

S. E. / N. S. 

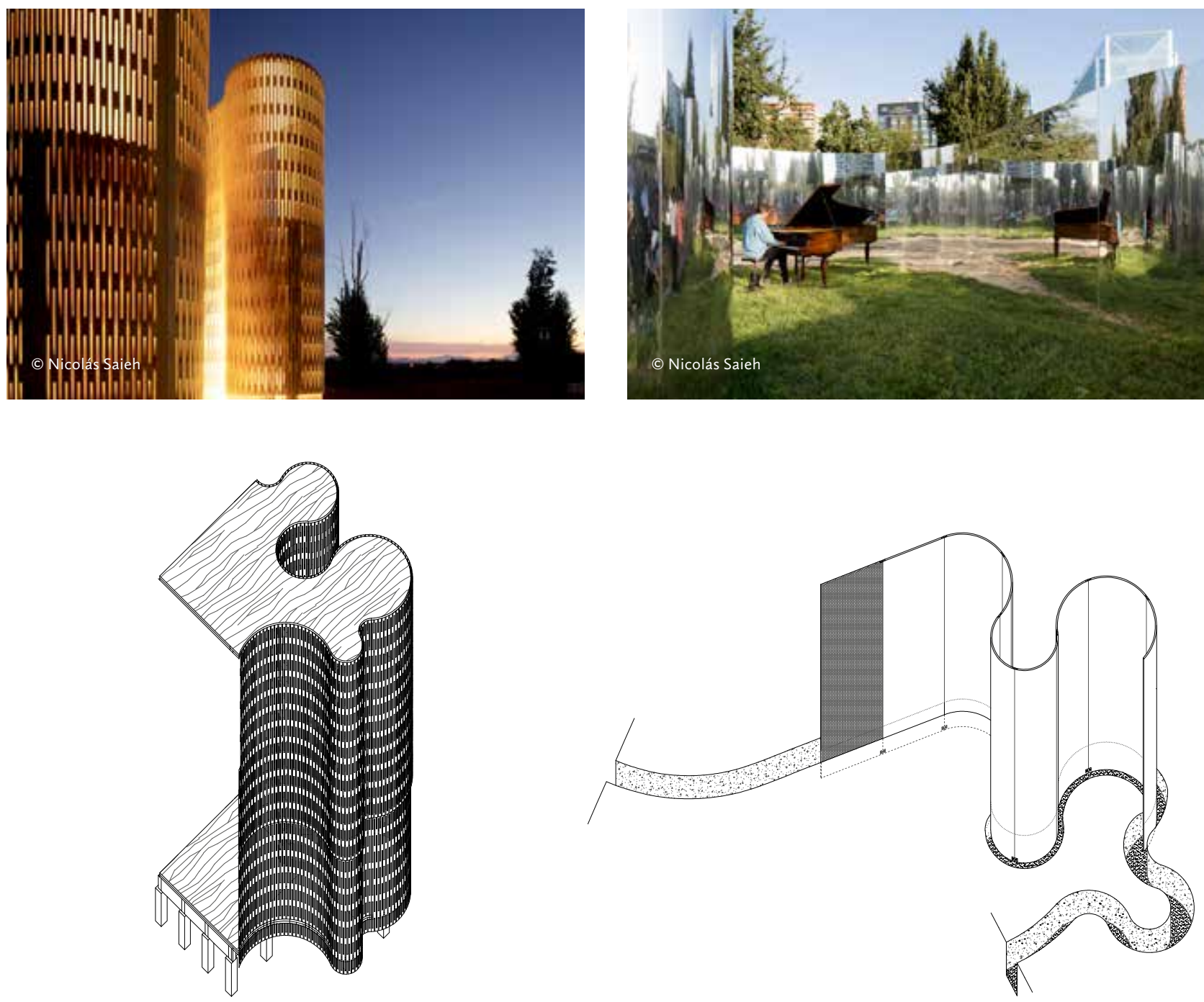

Detalle axonométrica / Axonometric detail

S. E. / N.S.
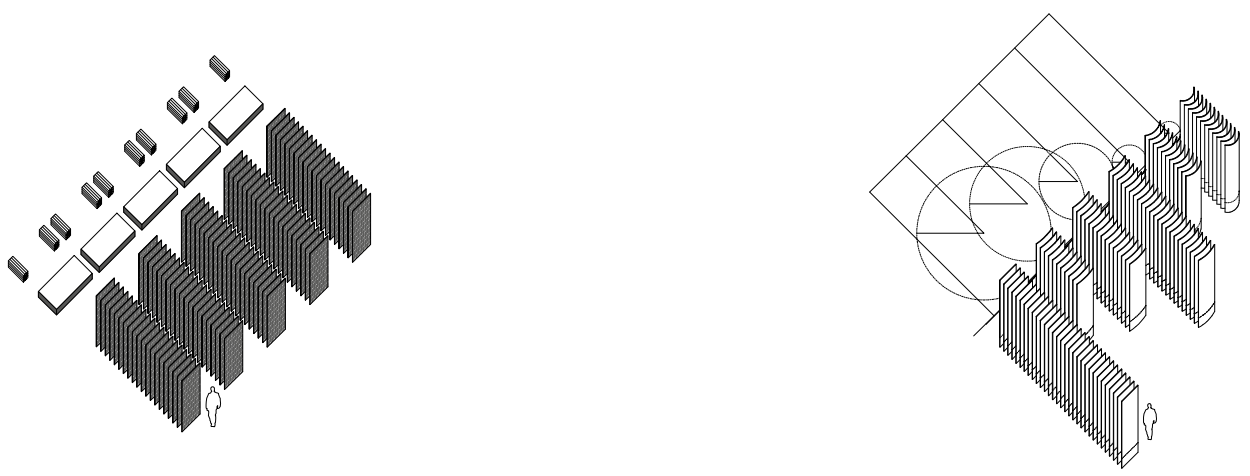

Axonométrica paneles / Panel axonometric

S. E. / N.S. 
LOS BOSQUES

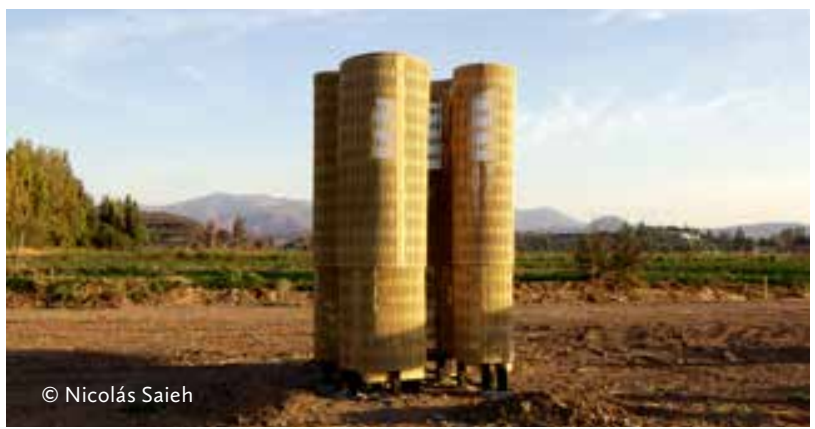

Nombre del proyecto / Project name

Los Bosques - Estación Cero

Arquitectos / Architects

Guillermo Hevia García, Nicolás Urzúa

Colaboradores / Collaborators

Eloy Bahamondes, Lucas Vásquez

Ubicación / Location

Curacaví, Chile

Cliente / Client

Constructo

Construcción / Building contractor

Patricio Parada, Cristóbal Parada

Sistema constructivo / Construction system

Placa madera contrachapada $18 \mathrm{~mm} / 18-\mathrm{mm}$ Wooden panels

Presupuesto / Budget

us $\$ 25.000$

Superficie construida / Built area

$$
40 \mathrm{~m}^{2}
$$

Año de proyecto / Project year

2013-2016

Año de construcción / Construction year

2014 (prototipo / prototype)

Fotografías / Photographs

Nicolás Saieh

\section{GUILLERMO HEVIA GARCÍA}

<gjhevia@uc.cl>

Architect, Pontificia Universidad Católica de Chile, 2011. School of Architecture Prize 2011. Since 2012 he is professor of studio at the School of Architecture uc, Chile. He won the Collective Housing Competition

"Habitat Colectivo". He currently works independently.

NICOLÁS URZÚA

$<$ nurzuai@uc.cl>

Undergraduate studies at Paris Malaquais University, France, 2008. Archi-tect, Pontificia Universidad Católica de Chile, 2011. Since 2014 he is professor of studio at the uc Architecture School. He currently works independently.
TU REFLEXIÓN

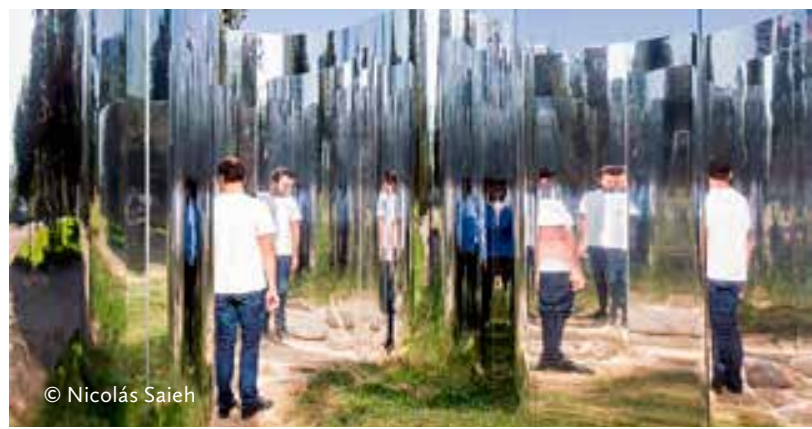

Nombre del proyecto / Project name

Tu Reflexión - yap Constructo o6

Arquitectos / Architects

Guillermo Hevia García, Nicolás Urzúa

Colaboradores / Collaborators

Felipe Droppelmann, Cristian Fuhrhop,

Cristóbal Montalbetti, Diego Rivera

Ubicación / Location

Parque Araucano, Las Condes, Santiago, Chile

Cliente / Client

Constructo

Construcción / Building contractor

Hunter Douglas Chile

Sistema constructivo / Construction system

Panel Honeycomb Aluminio Espejo $25 \mathrm{~mm} /$

25-mm Honeycomb Panel Mirrored Aluminium

Presupuesto / Budget

$$
\text { us } \$ 35,000
$$

Superficie construida / Built area

$600 \mathrm{~m}^{2}$

Año de proyecto / Project year

2015

Año de construcción / Construction year

2016

Fotografías / Photographs

Nicolás Saieh

\section{HEVIA + URZÚA}

Together they have been selected to represent Chile in the Iv Biennial of Latin American Architecture (BAL) Pamplona, Spain 2015, and won the IX Ibero-American Biennial of Architecture and Urbanism (BIAU)

Rosario, Argentina, 2014. They also won first place in the YAP_

Constructo 2015 competition with «Tu Reflexión» and in the contest Estación Cero (2013) with «Los Bosques». They obtained third place in the New FADEU UC Building in the Campus Lo Contador (2015) and the second place in the National Competition for the Extension of the National Historical Museum of Chile (2013). 